\title{
STUDI KOMPARASI PENINGKATAN HASIL BELAJAR MENGGUNAKAN MEDIA REALIA DENGAN MEDIA HANDOUT PADA MATA PELAJARAN ALAT UKUR
}

\author{
Verry A. Irawan ${ }^{1}$, Sabri $^{2}$, Asep H. Sasmita ${ }^{3}$ \\ Departemen Pendidikan Teknik Mesin \\ Universitas Pendidikan Indonesia \\ Jl. Dr. Setiabudhi No. 207 Bandung 40154 \\ vey_4b4h@yahoo.com
}

\begin{abstract}
ABSTRAK
Tujuan penelitian ini untuk mengetahui hasil belajar siswa yang menerapkan media handout dan media realia pada proses pembelajaran alat ukur mekanik presisi, serta mengetahui perbedaan peningkatan hasil belajarnya. Metode penelitian menggunakan metode quasi experimental design. Tipe kuasi eksperimen yang digunakan adalah non-equivalent control group design. Sampel dijadikan dua kelompok yaitu kelas kontrol diberi perlakukan handout dan kelas eksperimen diberi perlakuan media realita. Hasil penelitian menunjukan bahwa peningkatan hasil belajar pada mata pelajaran alat ukur dengan menggunakan media realia pada saat proses pembelajaran ternyata lebih besar dibandingkan dengan menggunakan media hand out. Hasil post-test pembelajaran dengan menggunakan media realia menunjukan peningkatan yang lebih besar .
\end{abstract}

Kata kunci: media, mekanik, presisi, handout, pengukuran

\begin{abstract}
The purpose of the research conducted to determine the learning outcomes of students who apply media handout on the learning process of mechanical precision measuring instruments, know the learning outcomes of students who apply really media, and know the difference between the increases in learning outcomes. The method in this study uses a quantitative approach to the method of quasiexperimental design. Quasi-experimental type used is the non-equivalent control group design. The results showed that increase learning outcomes in subjects measuring instruments using realia media at the time was more of a learning process compared to using the media handouts. The result by the posttest data results using really media showed greater improvement.
\end{abstract}

Keywords: media, precision, mechanical, handout, measuring

\footnotetext{
${ }^{1}$ Mahasiswa Departemen Pendidikan Teknik Mesin FPTK UPI

${ }^{2}$ Dosen Luar Biasa Departemen Pendidikan Teknik Mesin FPTK UPI

${ }^{3}$ Dosen Departemen Pendidikan Teknik Mesin FPTK UPI
} 


\section{PENDAHULUAN}

Salah satu tujuan pendidikan SMK mendidik sumber daya manusia yang mempunyai etos kerja dan kompetensi berstandar internasional (Ditpsmk, 2007). Tujuan SMK untuk mencetak orang-orang yang kompeten di dalam bidangnya. Salah satunya SMK Merdeka Soreang. Pada program keahlian teknik pemesinan ada beberapa mata pelajaran, salah satunya adalah mata pelajaran alat ukur. Diharapkan pada mata pelajaran tersebut siswa memiliki kompetensi dan semua siswa dapat meraih nilai yang amat baik. Realita yang terjadi tidak sesuai dengan harapan yang ingin dicapai, dimana pada mata pelajaran tersebut terdapat permasalahan pada hasil belajar siswa. Hasil belajar siswa belum optimal karena tidak ada satupun siswa yang mendapat nilai amat baik dan 13 orang belum tuntas dalam pembelajaran yang mengacu pada standar Kriteria Kelulusan Minimum (KKM). Berdasarkan kurikulum yang ada di SMK standar KKM ditunjukan dengan nilai adalah 71. Nilai di bawah standar tersebut dianggap belum tuntas.

Sumber belajar yang digunakan pada mata pelajaran tersebut adalah lembaran handout yang dijadikan sebagai media dalam pembelajaran. Dimana dalam penggunaannya guru menjelaskan ulang materi yang terdapat pada handout tersebut dengan penggunaan papan tulis sebagai sarana penegasan materi. Dengan kegiatan pembelajaran tersebut, berdampak kepada hasil belajar yang kurang memuaskan (Arikunto, 2010).

Proses belajar mengajar ada dua unsur yang sangat penting yaitu metode pembelajaran dan media pembelajaran (Arsyad, 2011). Penggunaan media pembelajaran yang tepat akan sangat membantu guru dalam menyampaikan materi ajar sesuai dengan tujuan pembelajaran yang hendak dicapai. Disamping itu, dalam pemilihan media pembelajaran sangatlah penting untuk diperhatikan ketepatan pemilihannya guna membantu menyampaikan materi ajar yang direncanakan.

Karakteristik materi ajar yang menuntut siswa untuk memperoleh pengalaman langsung dengan cara mengekplorasi terhadap bagian, penggunaan dan cara membaca skala ukur, terbatasi diakibatkan media yang digunakan kurang tepat dalam membantu menyampaikan isi materi ajar tersebut. Sehingga dapat diidentifikasi penggunaan handout dalam menyampaikan materi mengenai alat ukur sangat tidak tepat. Selain adanya keterbatasan tersebut, motivasi siswa dalam pembelajaran pun sangat rendah. Berdasarkan 
permasalahan tersebut, diperlukan adanya sebuah pemecahan masalah sebagai salah satu langkah perbaikan kualitas pembelajaran.

Sebagai langkah pemecahan masalah tersebut, dipandang penggunaan media realia sangat tepat guna siswa memperoleh pengalaman langsung dalam mengeksplorasi materi ajar berdasarkan tujuan pembelajaran. Realia merupakan alat bantu yang bisa memberikan pengalaman langsung kepada pengguna (Malino, 2012). Disamping itu, mudahnya penggunaan dan mendapatkan media realia untuk alat ukur menjadikan media ini sangat tepat untuk digunakan oleh guru sebagai media pembelajaran.

Tujuan penelitian ini adalah memperoleh besaran hasil belajar siswa yang menerapkan media handout dan realia pada proses pembelajaran alat ukur mekanik presisi. Diperoleh nilai perbedaan peningkatan hasil belajar antara kelas yang menerapkan media realia dengan kelas yang menerapkan media handout.

\section{METODE PENELITIAN}

Metode penelitian yang digunakan adalah eksperimental semu. Bentuk quasi eksperiment dianggap memiliki kemampuan memberikan perkiraan informasi yang diperoleh secara tepat mendekati penelitian eksperimen sesungguhnya pada penelitian pendidikan. Hal ini dikarenakan subjek yang dilakukan penelitian adalah manusia dimana variabel-variabel yang mempengaruhi sulit untuk dikontrol. Ada dua kelompok dalam penelitian ini yaitu kelompok kontrol diberikan perlakuan dengan media handout. Kelompok eksperimen diberikan perlakuan dengan media realia. Dilakukan tes pada kedua kelompok sebelum perlakuan sebagai dasar mengetahui besaran hasil belajar dan perbedaan nilai hasi belajarnya.

Sampel diambil dari dua kelompok, kelas kontrol dan kelas eksperimen. Kedua kelas tersebut diberikan pretest dengan soal yang sama. Pada kedua kelas diberikan perlakuan berupa pembelajaran dengan penggunaan media pembelajaran yang berbeda. Kelas kontrol diberikan pembelajaran menggunakan media handout sedangkan kelas eksperimen diberikan perlakuan dengan menggunakan media realia. Setelah perlakuan, kedua kelas tersebut diberikan soal posttest yang sama dengan pretest untuk mengetahui pengaruh perbedaan perlakuan yang diberikan. Responden sebanyak 30 orang untuk kelas kontrol dan kelas eksperimen. 


\section{HASIL PENELITIAN}

Uji coba alat tes, alat tes tersebut dikonsultasikan terlebih dahulu dengan dosen pembimbing. Setelah direvisi dan disetujui oleh dosen pembimbing, untuk lebih meyakinkan maka alat tes tersebut diuji cobakan kepada siswa kelas XI TPM 2 di SMK Merdeka Soreang yang tidak termasuk kedalam kelompok sampel penelitian. Jumlah peserta didik yang melakukan uji coba sebanyak 32 orang.

Uji coba alat tes dilakukan kepada 32 responden, untuk mengetahui kualitas alat tes penelitian sebelum diputuskan untuk dijadikan sebagai alat pengumpul data penelitian. Hasil pengolahan data untuk alat tes menunjukan bahwa alat tes dapat digunakan untuk kelas kontrol dan kelas eksperimen untuk mengetahui pemahaman menggunakan alat ukur mekanik presisi sebelum treatment dan sesudah treatment (Sudjana, 2009). Sehingga dapat diperoleh data mengenai peningkatan pemahaman alat ukur pada kelas kontrol dan kelas eksperimen. Hasil pre test kelompok kontrol yaitu rata-rata 6,5 dan rata-rata hasil postesnya 7.

Data hasil test siswa kelas kontrol. Pada pre-test nilai minimumnya adalah 5 nilai maksimumnya ialah 8 dan rata-ratanya adalah 6,5. Pada post-test nilai minimumnya adalah 5,5 dan nilai maksimumnya 8,5 serta dengan rata-rata 7. Data hasil test siswa kelas Eksperimen. Pada pre-test nilai minimumnya adalah 4 , nilai maksimumnya ialah 7,5 dan rata-ratanya adalah 5,5. Pada post-test nilai minimumnya adalah 6 dan nilai maksimumnya 9 serta dengan rata-rata 7,5 .

Peningkatan hasil belajar ( $N$-Gain) menggunakan alat ukur mekanik presisi siswa kelas kontrol dan eksperimen (Tabel 1.), dihitung dengan menggunakan gain yang ternormalisasi (N-Gain). Klasifikasi $N$-Gain (Hake, 1998), sebagai berikut: (1) jika $g \geq 0$,7, maka $N$-Gain termasuk kategori tinggi; (2) jika 0,7 > $g \geq 0,3$, maka $N$-Gain termasuk kategori sedang, dan (3) jika $g<0,3$, maka $N$-Gain termasuk kategori rendah.

Tabel 1. Peningkatan hasil belajar

\begin{tabular}{lcccc}
\hline \multicolumn{1}{c}{ Kelas } & $\begin{array}{c}\text { Rata-Rata } \\
\text { Pre-test }\end{array}$ & $\begin{array}{c}\text { Rata-Rata } \\
\text { Post-test }\end{array}$ & Rata-Rata Gain & $\begin{array}{c}\text { Rata-Rata } \\
\text { N-Gain }\end{array}$ \\
\hline Kontrol & 6,5 & 7 & 0,5 & $0,017 /$ Rendah \\
Eksperimen & 5,5 & 7,5 & 2 & $0,26 /$ Sedang \\
\hline
\end{tabular}




\section{PEMBAHASAN}

Media pembelajaran alternatif yang diterapkan pada penelitian ini adalah media realia dengan menggunakan benda nyata berupa jangka sorong dan micrometer luar. Setelah melalui tahap analisis data didapatkan bahwa peningkatan hasil belajar yang menggunakan media realia lebih baik dari pada peningkatan siswa yang menggunakan media hand out pada Mata Pelajaran Alat Ukur. Rata-rata peningkatan (N-Gain) penguasaan siswa yang menggunakan media realia termasuk kategori sedang, adapun rata-rata peningkatan ( $N$-Gain) penguasaan siswa yang menggunakan media hand out termasuk kategori rendah. Penerapan media realia pada pelajaran alat ukur dapat berhasil dengan baik, karena guru memahami beberapa kriteria yang harus dipertimbangkan dalam penggunaan realia yang seharusnya di gunakan. Oleh karena itu, guru berperan sebagai fasilitator untuk memberikan informasi.

Peningkatan hasil belajar dalam penelitian ini dikarenakan siswa di berikan kesempatan untuk melakukan pengukuran sendiri secara langsung. Hal tersebut sesuai dengan fungsi dari media realia, guru memberikan pengarahan dengan melakukan pengukuran secara langsung pada benda kerja. Siswa diberikan waktu cukup untuk melakukan pengukuran sendiri pada benda kerja secara langsung.

\section{KESIMPULAN}

Proses pembelajaran dengan menerapkan media handout pada mata pelajaran alat ukur kurang tepat, dikarenakan nilai hasil belajar yang kurang memuaskan sehingga berdampak terhadap banyaknya nilai siswa yang belum mencapai KKM. Proses pembelajaran dengan menerapkan media realia pada mata pelajaran alat ukur terbukti lebih baik, dikarenakan hasil dari pembelajaran tersebut semua nilai siswa telah mencapai KKM. Peningkatan hasil belajar pada mata pelajaran alat ukur dengan menggunakan media realia pada saat proses pembelajaran ternyata lebih besar dibandingkan dengan menggunakan media handout, terbukti dengan hasil data post-test dengan menggunakan media realia menunjukan peningkatan yang lebih besar .

\section{DAFTAR PUSTAKA}

Arikunto, S. (2010). Dasar-dasar Evaluasi Pendidikan. Jakarta: Bumi Aksara

Arsyad, A. (2011). Media Pembelajaran. Jakarta: Raja Grafindo. 
Hake, R.R.(1999).Analyzing Change/Gain Scores.[online] Tersedia: http://lists.asu.edu/cgibin/wa?A2=ind9903\&L=aera-d\&P=R6855. [10 oktober 2010].

Malino, Jupri.(2012). Pengertian Definisi Media Nyata Realia, Bentuk, Karakteristik dan Pemilihan Media Realia.[Online].Tersedia: http://juprimalino.blogspot.com/2013/05/ pengertian-definisi-media-nyata-realia.html.

Sudjana, N. (2009). Penilaian Hasil Proses Belajar Mengajar. Bandung: Remaja Rosdakarya. 